\title{
The IWMA and Its Precursors in London, c. $1830-1860$
}

\author{
Fabrice Bensimon
}

The discussion of the origins of the International Working Men's Association (IWMA) is as old as the Association itself. Right from its beginnings, the founding members defined what they saw as its origins. Since then, and in particular with the development of a scientific study of the IWMA in the twentieth century, several questions have been raised. The first is the militant origins in the various steps to the founding of the association on 28 September 1864. Who were these activists? Did the scheme of an international association of workers originate long before, or just recently? Was it a linear or rather a protracted progress? What were the meanings that were given to "internationalism"? Another question relates to the longer-term assessment of the growth of working-class internationalism: did it exist, and if it did, according to what patterns did it develop? A possible third question is the study of its fortune: why was the IWMA so different from previous attempts?

Two broad approaches have been used. The "internal" one, best exemplified by the work of Arthur Lehning, has been the minute research on individuals, on the small groups of refugees, trade unionists and political activists whose ideas and commitments led to the creation of the IWMA. ${ }^{1}$ A more "external" approach has consisted in addressing the issue of why this association in particular was so successful, while others had failed before: were economic circumstances different? Had labour markets changed? Had working-class practices been transformed in Britain and on the continent? And so on. In a paper given at the 1985 conference in Amsterdam for the 5oth anniversary of the International Institute of Social history (IISH), Marcel van der Linden thus offered a "structural" interpretation for the rise and fall of the IWMA. "Whereas

* This paper has benefited from the readings and advice of Michel Cordillot, Quentin Deluermoz, Jürgen Herres, Detlev Mares, Jeanne Moisand and Iorwerth Prothero, who are warmly thanked here.

1 Arthur Lehning, From Buonarotti to Bakunin. Studies in International Socialism (Leiden, 1970).

2 Marcel van der Linden, "The rise and fall of the First International: an Interpretation", in Frits Van Holthoon and Marcel van der Linden (eds), Internationalism in the Labour movement, 1830-1940, 2 vols (Leiden, 1988), 1, pp. 323-335.

(C) FABRICE BENSIMON, 2018 | DOI 10.1163/9789004335462_003

This is an open access chapter distributed under the terms of the prevailing CC-BY-NC License. 
hitherto the rise and fall of this organization was usually and to a large extent accounted for in terms of contingent factors, and 'voluntarist' choices made by its leaders", he wished "to stress the more or less anonymous forces that played a role in this process." Namely, in the economic sphere, the dramatic growth of industrial output and of world trade; the formation of nation-states; and the making of national organizations, trade unions in particular.

These two approaches are not mutually exclusive, and combining the two helps shed light on a number of issues. While other contributions insist on the context of the making of the IWMA and on the reasons for its relative success, this paper focuses on its internal pre-history. In particular it tries to address the protracted question of what defined internationalism, and in particular what made it different from cosmopolitanism and from the international solidarity, e.g. with Poland, which existed before. The reference to London does not imply that there were no origins of the IWMA elsewhere - had it come solely from London, the IWMA would not have proved as influential among workers internationally. This simply means that the focus is London and Britain, which happened to be the birthplace of the IWMA, though its parent organisations came from various places. It seems that the amount of novel work concerning the late 185 os has been rather limited since Lehning's 1938 text. This will be rather briefly discussed after a longer and more detailed analysis of the pre-1848 period and the Fraternal Democrats in particular.

\section{Exiles, Migrants and Internationalism in London before 1848}

Why did London play a key part in the origins and the making of the IWMA? Above all, because it was the capital of political exile. If we compare the state of research today with 1964, we can say that on this point several significant works have supplemented our knowledge. Bernard Porter has studied how London became, especially after 1848 , the main centre for political asylum in the world. ${ }^{4}$ Although Britain did nothing to smoothe the exile of republicans and socialists, it was a liberal country, where many people felt attached to this policy of hosting the victims of foreign tyrannies - at a time when British radicals were proud of the liberties granted by the constitution of their country. It was also a powerful state, which made it easier than for countries such as Belgium or Switzerland to resist the pressure of France, Austria, Prussia or whatever regime was unhappy with the activities of its unruly subjects on British soil. Our knowledge of the lives of the refugees has now much improved.

3 Ibid., p. 323.

4 Bernard Porter, The Refugee Question in mid-Victorian Politics (Cambridge, 1979). 
Several monographs and edited volumes have tackled the social history of groups of exiles, in particular Sylvie Aprile and Thomas C. Jones on the French, Rosemary Ashton and Christine Lattek on the Germans, Juan Luis Simal on the Spanish and Maurizio Isabella on Italians. ${ }^{5}$ Miles Taylor and Margot Finn have referred to the interactions between various refugees and groups and former Chartists, and they have shown how the latter's presence contributed to redefine British radicalism. These works document the rich associational life of exiles, including their lesser known members, as well as the interactions between the members of various groups. The bulk of this research focuses on the post-1848 era, when thousands went to Britain following the 1848-1849 revolutions. But from the 1820 , Germans, Italians, Spanish, Frenchmen or Poles found refuge in Switzerland, Belgium, France and above all Britain. ${ }^{6}$

Another dimension was the circulation of ideas. Early socialist thinkers, like Charles Fourier, Saint-Simon, Robert Owen and later Étienne Cabet conceived systems that relied on universal brotherhood. Gregory Claeys has argued that Owenism played a significant part in the genesis of internationalism, in particular in the 1840 os with the Owenite Association of All Classes of All Nations (founded in 1835), which had branches in the United States and correspondence with France, Belgium and Germany. ${ }^{7}$ Under the incentive of some of their followers, several texts were translated which facilitated the diffusion of radical and socialist thought, e.g. Bronterre O'Brien's translation of Buonarroti's History of Babeuf's Conspiracy for Equality (1828) in $1836 .^{8}$

5 Sylvie Aprile, Le Siècle des Exilés. Bannis et proscrits de 1789 à la Commune (Paris, 2010); Thomas C. Jones, "French republican exiles in Britain, 1848-1870" (Ph.D., University of Cambridge, 2010); Thomas C. Jones and Robert Tombs, "The French left in exile: quarante-huitards and communards in London, 1848-80", in Debra Kelly and Martyn Cornick (eds), A History of the French in London: liberty, equality, opportunity (London, 2013), pp. 165-191; Rosemary Ashton, Little Germany: exile and asylum in Victorian England (Oxford, 1986); Juan Luis Simal, Emigrados. España y el exilio internacional, 1814-1834 (Madrid, 2012); Christine Lattek, Revolutionary Refugees: German Socialism in Britain, 1840-1860 (London, 2005); Sabine Freitag (ed.), Exiles from European Revolutions, Refugees in Mid-Victorian England (New York, 2003).

6 Bernard Porter, The Refugee Question; Delphine Diaz, Un asile pour tous les peuples ? Exilés et réfugiés étrangers dans la France du premier XIXe siècle (Paris, 2014).

7 Gregory Claeys, "Reciprocal dependence, virtue and progress: some sources of early socialist cosmopolitanism and internationalism in Britain, 1750-1850", in Frits Van Holthoon and Marcel van der Linden, Internationalism in the Labour movement, 1830-1940, 2 vols (Leiden, 1988), I, pp. $235^{-258 .}$

8 Filippo Michele Buonarroti, Buonarroti's History of Babeuf's Conspiracy for Equality; with the author's reflections on the causes and character of the French Revolution. Translated by Bronterre [James Bronterre O'Brien] (London, 1836). 
Lehning identified the 1830 s as a primary period of intercourse, when some working-class newspapers started reporting on foreign labour movements, e.g. L'Écho de la fabrique in Lyon (1831-1834), The Poor Man's Guardian in London (1831-1835). In 1836 William Lovett's "London Working Men's Association" drafted an Address to the Belgian Working Classes which may have been the first written statement of working-class internationalism, starting: "Fellow Producers of Wealth -, We are of opinion that those who produce the real wealth of any country (by which terms we mean the food, clothing, habitations, and all the great essentials of human happiness) have in reality but one great interest" ${ }^{9}$ Similar addresses sent in the following years to the "workers" of various nations testified not only to the concern of setting up connections between organizations, but also to existing contacts. Following the repression of the 1830-1 Polish uprising, the Polish cause had featured prominently in the manifestations of international solidarity. Hundreds of Poles had emigrated to Britain - by 1845 , there were some 500 of them on British soil. ${ }^{10}$ Many belonged to the small landowning nobility. But others were democrats; and Poland became the most important cause célèbre in radical circles in Britain, as well as France."1 The British public was outraged by the reported brutality of the Russians against the Poles, against Polish women in particular. ${ }^{12}$

The 1840 may nevertheless be considered a turning point. L'Atelier (1840-50), Cabet's Populaire (1841-51) and the Deutsch-Französiche Jahrbücher (1844) in Paris, the Rheinische Zeitung (1842-43) in Köln, the Schweizerischer Republikaner (1830-46 and 1848-51) in Zürich, the Owenite The New Moral World in London and Leeds (1834-45), George Jacob Holyoake's Movement in London (1843-45), and the Chartist Northern Star in Leeds and London (1837-52) all reported on foreign labour movements. These newspapers can help us assess the larger impact of movements which have often been only thought of as national; for example L'Atelier and Le Populaire did not just deal with Chartism: they celebrated it and tried to find inspiration in it. In France, by 1843, feminist thinker Flora Tristan (1803-44) was trying to set up the Union ouvrière, which she wanted to be an international organization. In London, numbers

The Working Men's Association of London to the Working Classes of Belgium (London, 1836). This was published in The Constitutional (London, 12th November 1836), and is reproduced in appendix in Lehning, From Buonarotti to Bakunin, pp. 210-214.

10 Krzysztof Marchlewicz, "Continuities and Innovations: Polish Emigration after 1849", in Sabine Freitag (ed.), Exiles from European Revolutions, p. 105.

11 Henry Weisser, "Polonophilism and the British Working Class, 1830 to 1845 ", The Polish Review (1967), 2, pp. 78-96; Henry Weisser, "The British Working Class and the Cracow Uprising of 1846", The Polish Review (1968), 1, pp. 3-19.

12 E.g.: Northern Star (15 June 1844), p. 6. 
of refugees and migrants had swollen. Contacts between radicals, republicans and socialists multiplied and led to the creation of organizations of exiles which, in turn, led to the creation of the Fraternal Democrats (FD, 1845-8), presumably the first international organization. ${ }^{13}$

The German Democratic Society, the London Chartists and, to a lesser degree, French and Polish refugees, were instrumental in the founding of the FD. A small group of French neo-Babouvists, the Société démocratique française (SDF, 1835?-48), had met in London. Camille Berrier-Fontaine (1804-82), a former secretary of the Central committee of the republican "Société des Droits de l'homme" and a friend of Cabet, led the SDF in $1840-5$, before being succeeded in $1845^{-8}$ by Jean Juin (b. 1797), alias Jean Michelot, who informed the French police. ${ }^{14}$ This group met in the Red Lion, a pub in Great Windmill Street, in Soho which was the district where many exiles lived. From 1840, the Red Lion also became the meeting place of the better-known "Deutscher Bildungsverein für Arbeiter", which became famous as the Communisticher Arbeiter-Bildungsverein (CABV) or Communist Workers' Educational Society (1840-1919). ${ }^{15}$ This was primarily composed of German artisans in London and was led by Joseph Moll, Heinrich Bauer and above all Karl Schapper. Several of its leaders had been involved in the 12 May 1839 rising in Paris, led by Auguste Blanqui, Armand Barbès and Martin Bernard, and were therefore acquainted with French exiles.

In 1844, Owenite and "Moral force" Chartist William Lovett had founded the "Democratic Friends of all Nations" with continental refugees like Schapper, Ludwik Oborski (1787-1873) and Berrier-Fontaine as members. Lovett rejected the class struggle and his scheme was more of a humanist internationalism. Little is known about this group, apart from the fact that Lovett soon resigned from it, that it was short-lived and that only two documents it penned have survived. ${ }^{16}$

13 Henry Weisser, British working-class movements and Europe. 1815-1848 (Manchester, 1975), pp. 134-171; Salvo Mastellone, “ « Northern Star », Fraternal Democrats e Manifest der Kommunistische Partei", Il pensiero politico, 37, 1 (2004), pp. 32-59; Malcolm Chase, Chartism: A New History (Manchester, 2007), Ch. 9.

14 François Fourn, Etienne Cabet, ou le temps de l'utopie (Paris, 2014).

15 Christine Lattek, Revolutionary Refugees, p. 25.

16 Christine Lattek, "The beginnings of socialist internationalism in the 1840s: the 'Democratic Friends of all Nations' in London", in Frits van Holthoon and Marcel van der Linden, Internationalism in the Labour movement, 1, pp. 259-282. Lattek noted (p. 260) that these two documents were: “The Democratic Friends of All Nations, Meeting at No. 20 Great Windmill Street Haymarket; On the first Wednesday of every month at 8 o'clock in the evening", signed by Carl Schapper (19 October 1844) and printed in the New Moral World (2 November 1844); and the eight-page pamphlet, "All Men are Brethren". An Address to the 
Christine Lattek has described it as a "bridge and a transition between earlier forms of republican and democratic cosmopolitanism and later socialist internationalism". ${ }^{17}$ But its impact was far more limited than the FD. By 1845 , while the SDF was probably declining, the CABV was soaring. Thanks to the economic migration of "tramping artisans", even more than political exile, it went from about 30 members to some 300 early in 1847 , "with another 160 in a branch founded in Whitechapel in July 1846 , and eventually reached a strength of 700" before $1848 .{ }^{18}$ It included members from various countries where German was partly spoken: Swiss, Dutch, Scandinavians, Czechs and Hungarians. ${ }^{19}$

The creation of the FD resulted from contacts between these organisations and British Chartists, especially two leaders with "internationalist" beliefs: Ernest Jones, who had grown up in Germany and had a great knowledge of continental affairs, and above all George Julian Harney (see figure 2.2). Born in 1817 into poverty, Harney had been educated in what he described as the "radical school of the thirties". ${ }^{20} \mathrm{~A}$ Chartist since the birth of the movement, he had become a full-time organiser and the sub-editor of its main paper, the Northern Star. When the Star moved to London in November 1844, it settled in Great Windmill Street and the favourite pub of the board was the Red Lion.

Although the FD were probably created in 1844 and then held a meeting against the Russian Czar visiting Britain, their official birth dates from 22 September 1845, with the meeting of reportedly "more than one thousand" that was held to commemorate the establishment of the first French Republic, with some British, German, French, Italian, Polish and Swiss members. ${ }^{21}$ Toasts were taken to Young Europe, to Thomas Paine, to the "fallen Democrats of all countries" and to those of England, Scotland and Ireland, to transported Chartists; democratic songs in all languages were sung. The meeting brought

Friends of Humanity and Justice among all Nations, by the Democratic Friends of all Nations (London, 1845). Parts of this were quoted in William Lovett, Life and Struggles of William Lovett (London, 1967), pp. 256-257.

17 Christine Lattek, "The beginnings of socialist internationalism in the 1840s", p. 282.

18 Christine Lattek, Revolutionary refugees, p. 32.

19 Ibid., p. 33 .

20 David Goodway, "Harney, (George) Julian (1817-1897)", Oxford Dictionary of National Biography (Oxford, 2004); A.R. Schoyen, The Chartist Challenge; a Portrait of George Julian Harney (London, 1958).

21 See extensive report on the meeting by Engels, Rheinische Jahrbücher zur gesellschaftlishcen Reform (1846), reproduced in Karl Marx and Frederick Engels, Collected Works (London, 1975), 5, pp. 3-14; The Northern Star, 411 (27 September 1845). See also: Salvo Mastellone, « 'Northern Star', Fraternal Democrats e Manifest der Kommunistische Partei ». 
home the idea that a fraternization of the nations was only possible through a union of the workingmen, the proletarians alone being capable of fraternization. From then on, several meetings of the FD gathered hundreds to celebrate French revolutionary events or the German Hambach Festival late in May.

This leads us to the nature of the "internationalism" of the FD. Where did it come from? And what did it mean? This idea of a workingmen's union did not come from the French: like most French republicans, the SDF considered their republic the model, although it largely debated Chartism and what could be learnt for a possible uprising in Paris, and also advocated a "universal brotherhood of the people" of France and Great Britain. ${ }^{22}$ In Britain, most radicals and Chartists, e.g. Feargus O'Connor, were long convinced that freedom was a preserve of the English constitution. Among Italians or Poles, national sentiment often predominated. Two more reliable sources for the internationalism of the FD are the Germans and Harney. Harney reported on and debated foreign affairs, denounced British colonial enterprises and advocated the unity of workers across Europe - he was the inspiration and the driving energy of the FD. The CABV was dedicated to seemingly innocuous education purposes, but was in fact subordinated to the secret League of the Just, led by Schapper and by Weitling, and which supervised its "functions and public proclamations" and "used it for agitation, discussion and recruitment". ${ }^{23}$ In June 1847, the League became the "League of the Communists". Late in November 1847, Marx and Engels attended the second Congress of the Communist League (29 Nov.8 Dec.), held in the Red Lion, which famously directed them to write a statement, which became the Manifest der Kommunistischen Partei, published in February 1848 with its famous conclusive call: "Proletarians of All Countries, Unite!" This evolution in the meaning of internationalism, from a form of universal brotherhood, to a working-class war cry, was replicated once more in the IWMA.

Having an international organization, i.e. including people from different countries, did not equate with internationalism. ${ }^{24}$ For the FD as for many other

22 See the address to the 1839 Chartist Convention with an internationalist message in the mode of the Thomas Paine: "Democrats of Great Britain! Our two countries were many years rivals ... We desire with all our hearts, the intimate union of the nations - the most civilised in the world - the result of which would be liberty. We wish for the universal brotherhood of the people". The Charter (28 July 1839), p. 428, quoted in Henry Weisser, British working-Class Movements and Europe (Manchester, 1975), p. 86.

23 Christine Lattek, Revolutionary Refugees, p. 26.

24 Address of the Fraternal Democrats assembling in London to the working classes of Great Britain and the United States (4July 1846); The Democratic committee for Poland's regeneration, to the People of Great Britain and Ireland (London, 7 December 1846); The Fraternal 
radicals, the Polish cause was an essential one and they supported the Polish insurrection in 1846. Of course, supporting foreign causes was not synonymous with internationalism either. But the FD also opposed the possibility of war between Britain and the USA on the Oregon question in 1846 - "No vote! No musket!!" they claimed. They advocated the gathering of a Congress of Nations to settle international disputes. ${ }^{25}$ And in January 1848 , when there was an invasion scare in Britain, they denounced it, opposing the idea of wars, and adding: "While denouncing international wars, we do not share the sentiments of those who consider all war unjustifiable. We, on the contrary, assert that as long as tyranny reigns there can nor should be peace between the oppressed and the oppressors." 26 This advocacy of "physical force" as well as class struggle meant that the "moral force" Chartists did not join and founded instead in 1847 a "People's International League" which advocated internationalism along Mazzinian lines. In September 1847, the FD issued a manifesto which asserted democratic as well as internationalist principles:

We condemn the "national" hatreds which have hitherto divided mankind, as both foolish and wicked. [...] Convinced, too, that national prejudices have been, in all ages, taken advantage of by the people's oppressors, to set them tearing the throats of each other, when they should have been working together for their common good, this society repudiates the term "Foreigner", no matter by, or to whom applied. Our moral creed is to receive our fellow men, without regard to "country", as members of one family, the human race. ${ }^{27}$

This support for harmony and peace between states and an end to war prevailed as well among some free-traders, e.g. Richard Cobden, Frédéric Bastiat or Arlès-Dufour. But Harney and most FD members went further, with this emphasis on the common interests and the fraternization of workers regardless

Democrats (assembling in London) to the Democracy of Europe (7 December 1846); Address of the Fraternal Democrats assembling in London, to the members of the National Diet of Switzerland (13 December 1847); Principles and rules of the Society of Fraternal Democrats, n.d.

25 Address to the Working Classes of Great Britain and the United States on the Oregon Question, printed in Northern Star, 7 March 1846; Address of the Fraternal Democrats assembling in London to the working classes of Great Britain and the United States, 4 July 1846. These tracts are also in the British Library, 1852.e.4.

26 "The Fraternal Democrats assembling in London to the proletarians of France", Northern Star (5 February 1848), p. 8.

27 Principles and rules of the Society of Fraternal Democrats (London, 13 December 1847). 
of nationality, fighting together against their rulers: "The cause of the people in all countries is the same - the cause of labour, enslaved and plundered labour". ${ }^{28}$ Harney was coming close to the formulation of Marx and Engels and the League of the Communists. Thus, it can be argued that on the eve of the 1848 revolutions, Harney and the FD had moved to positions close to the "worker's internationalism" that could be found in the Communist Manifesto, which was drafted late in 1847 and early in 1848 . After 1848 , Harney would advocate for "The Charter and something more", i.e. rely on continental socialism so as to complement the Chartist agenda. In 1850, his paper The Red Republican would publish the first English translation of the Marx and Engels's Manifesto.

The FD had branches outside London - about 20 -, as can be understood from the reading of the Northern Star. By December 1847, they had a set of rules, membership cards, and conditions for membership (see figure 2.1). They were able to gather thousands, e.g. on the Polish question on 25 March 1846 when, as a police report to Guizot informs us, among the workers attending: "2,00o stayed until the end, and another thousand was renewed at least four times from eight o'clock to midnight". ${ }^{29}$ They were not an international working-class organization proper: their membership was cosmopolitan, but mostly in Britain. But their formal structure with an international committee including representatives of affiliated national sections, was both new and something the IWMA reproduced.

Some continental newspapers such as La Réforme, Rheinische Jahrbücher zur Gesellschaftlichen Reform or Deutsche-Brüsseler Zeitung in Brussels reported on their meetings. Since 1846, Marx had a scheme of establishing an international correspondence committee to keep the socialists in France, Britain and Germany aware of their respective ideas. Late in 1847 , Harney, alongside Marx and Engels, who were now in Brussels, tried to set up an international organisation. This decision was, in a way, a response to the Free Trade Congress held in Brussels in September $1847 .^{30}$ The FD had contacts in France and Belgium, but this was short-lived: the French and the Germans who had been involved returned home to take part in the 1848 revolutions. The FD did not disband immediately. They elected a delegation of three (Jones, Harney and Philip McGrath) who

$28 \quad$ Northern Star (14 February 1846).

29 «...200o restent jusqu'à la fin, l'autre mille se renouvelle au moins quatre fois de 8 heures à minuit... ». Rapport transmis par le préfet de police à Guizot (26 mars 1846), Archives nationales, Fonds Guizot, $42 \mathrm{AP} / 57$.

30 See [Friedrich Engels], "The Free Trade Congress at Brussels", The Northern Star (9 October 1847) with an editorial note: "From Our German Correspondent". Reproduced: http://www.marxists.org/archive/marx/works/1847/og/30.htm. 
went to Paris with Schapper, Moll and Bauer to hail the February revolution and congratulate the Provisional Government. They suffered not just from the departure of many of their foreign members, but also from the general decline of Chartism following 1848. In April 1848, in the context of the continental revolutions and of a revival both of Chartism and of Irish agitation for repeal, the government accused foreign agitators and Parliament passed an Alien Act, which led to the FD only having British members. Although they survived until 1854, they never truly recovered from 1848 .

\section{From the Flotsam of Revolutions to a Working-Class Upturn (1848-1860)}

However, the flotsam of the 1848 revolutions was followed by a new influx of refugees in London. By 1852, there were possibly 4,500 French refugees in London - and still 1,00o in 1853 - as well as 1,300 Germans and 2,500 Poles and Hungarians. ${ }^{31}$ While refugees were under the surveillance of the authorities, they could generally keep on meeting and editing newspapers. A fraction of the British population was very attached to this right to asylum; this was obvious on several occasions, including the mobilization against the eviction of Simon Bernard, in 1858, following the Orsini bombing against Napoleon III. While the "forty-eighters" were bitterly divided, they wrote to and read one another. Moreover they were able to assemble in various opportunities that the radical social life of London in the 1850 offered: clubs, banquets, public meetings, "soirées" as well as funerals. ${ }^{32}$

As André Combes and Boris Nicolaevsky have argued, there was also among the freemasons a sociability of exiles which transcended their political cleavages. ${ }^{33}$ Combes noted that Talandier and other members of the "Commune révolutionnaire" belonged to the lodge of the "Philadelphes", in London, which blossomed and, following the paths of exile, tried to set up freemason's

\footnotetext{
31 Bernard Porter, The Refugee Question, p. 16.

32 See Iorwerth Prothero, "Chartists and Political Refugees", in Sabine Freitag (ed.), Exiles from European Revolutions., pp. 209-233; Sylvie Aprile, Les Siècle des exilés.

33 André Combes, « Des Origines du Rite de Memphis à la Grande Loge des Philadelphes, 1838-1870 (d'un Rite 'mystique' à une Obédience révolutionnaire) », Chroniques d'Histoire maçonnique, 34 (1985), pp. 39-62; Boris I. Nicolaevsky, "Secret Societies and the First International", in Milorad Drachkovitch (ed.), The Revolutionary Internationals, 1864-1943 (Stanford, 1966), p. $36 \mathrm{ff}$.
} 
lodges abroad, in Brussels, New York (Pelletier and Berjeau), Geneva and even Ballarat (Jean-Marie Ballaguy), in Australia. ${ }^{34}$ Claude Pelletier, the founder of the lodge in New York, was also one of the founders of the International Association in the us. Victor Le Lubez, a future member of the General Council of the IWMA, was also a freemason. So was Auguste Séraillier (b. 1840), who was later trusted by Marx as his man in Paris during the siege of Paris and the Commune. Séraillier had married Eugénie "Jenny" Berjeau (b. 1842), the daughter of another exile, Jean Berjeau, a freemason who was one of the main organisers of the « Société fraternelle des démocrates-socialistes », which was founded in $185^{\circ}$ and was most likely of masonic origin. ${ }^{35}$ But these meetings were inherently secret, and it is unlikely that much else will be known about them in the future.

The International Committee (IC, 1854-6) and the International Association (IA, 1856-9) were typical examples of this associational life among radicals in London. Founded by Chartists to welcome Armand Barbès who had been pardoned by Napoleon III, a committee was extended to protest against the Emperor's visit to Britain. The "welcome and protest committee" created in the autumn of 1854 transformed into an "International Committee" in February 1855. It was headed by British Chartists, German and French refugees, one Spanish representative and announced the joining of Poles and Italians. ${ }^{36}$ The IA was founded on 10 August 1856 at the John Street Institution. It was dedicated to "social revolution" and the "emancipation of the proletariat" and even denounced "fraternity" as a "silly illusion where society is founded on classes and castes". ${ }^{37}$ It opposed Mazzini and any union of the classes in support of democracy and national independence. It gathered four national groups: the French group of exiles named the "Commune révolutionnaire", who, around Félix Pyat and Alfred Talandier, objected to Ledru-Rollin and Louis Blanc, whom they saw as partly responsible for the defeat of the 1848 revolution; the German CABV with Karl Schapper; the waning Chartists under the leadership of Ernest Jones; and the Polish Socialists (Gromada Rewolucyjna Polska) with Oborski, a former leader of the military branch of the patriotic society in

34 See Combes, « Des Origines du Rite de Memphis à la Grande Loge des Philadelphes », pp. $5^{0}-51$.

35 I owe this information to Michel Cordillot.

36 People's Paper (21 October 1854, 20 January 1844), quoted in Margot Finn, After Chartism, p. 136.

To the Republicans, Democrats and Socialists of Europe (London, 1858). 
Warsaw and who had already been a member of the FD. ${ }^{38}$ On both the IC and the IA, we don't know much more than what was already in Lehning's detailed 1938 piece $^{39}$ The main activities of these associations were the celebrations of the traditional calendar of radical anniversaries: the first French Republic, the Polish rising in 1830 , the days of February and June $1848 .^{40}$ The IA declared that both men and women were entitled to equal rights and its membership was open to women, which was quite unique by the late 1850 s. French socialist and feminist refugee Jeanne Deroin was invited to address the Association and argued that a democrat could not object to equality between men and women. ${ }^{41}$ Although they did not always agree, participants insisted not only on brotherhood among the people, but also on the "tyranny of capital." The IA had a "Central Council" - something the IWMA would reproduce - and it published a bulletin before it faded in 1859 . The number of 1848 exiles diminished in Britain, in particular among the French following the 16 August 1859 amnesty. The last convention of the National Charter Association had met in 1858 and several leaders were moving towards liberalism, e.g. Ernest Jones himself. In 1861, with the Prussian amnesty, some German refugees also were repatriated. ${ }^{42}$ As Michel Cordillot has shown, the IA also managed to take root in the Us up until the time of the Civil War, among German and French exiles; it had branches in New York, Boston, Cincinnati and Chicago. ${ }^{43}$

Lehning wrote that the IA might be regarded as "the first international organization of a proletarian and socialist character, and forms the last and most important link in the series of international manifestations during the three decades prior to the foundation of the First International".44 This should probably be nuanced as there were disagreements in its ranks, including on the socialist agenda. Henry Collins and Chimen Abramsky offered a slightly different assessment. "The influence of the Association remained small and it died almost unnoticed in 1859", they wrote - "rather a herald of the future than

38 B. Cygler, Pulkownik Ludwik Oborski. Szermierz wolnosci 1789-1873 [Colonel Ludwik Oborski - An Advocate of Freedom] (Gdansk, 1976).

39 Reproduced in Lehning, op. cit.

40 Margot Finn, After Chartism p. 137.

41 Ibid., p. 204.

42 Ibid., p. 205.

43 Michel Cordillot, Utopistes et exilés du Nouveau Monde. Des Français aux États-Unis de 1848 à la Commune (Paris, 2013), pp. 171-187.

44

Lehning, op. cit., p. 191. 
a thing of actual flesh and blood". 45 Its influence was definitely very limited beyond its own ranks, but it was important among exiles. In the USA, for instance, all the leaders of the IA were later those of the IWMA branch.

The link between the refugee culture and the IWMA was obvious in the interest in foreign affairs: Italian unification, the abolition of serfdom in Russia, the American civil war were issues which raised the interest or resulted in the mobilization among large sectors of the working class. The issue of Poland continued to remain important, as exemplified by the 22 July 1863 meeting when five French delegates - including Tolain -, all future founders of the IWMA in France, came to take part in a meeting of support in London. The 1863 Polish uprising led to the creation of the National League for Polish Independence, which demanded Franco-British intervention in support of the Poles. This support of foreign movements of liberation was not necessarily in support of peace, as many wanted intervention against reactionary forces. Another example was in April 1864, when tens of thousands of Londoners hurried to greet Garibaldi when he briefly visited Britain, and another committee in Paris also sent a delegation to London.

More "external" factors led to the success of the association which was founded on 28 September 1864. Following the improvements in transport, the rise in migration flows, and the gradual development of a European labour market, the recruitment of workers abroad to break strikes became more common in the $1850 \mathrm{~s}$. Attempts to prevent this had existed since the strikes of the tin-plate workers in Wolverhampton in 1851 and Birmingham in $18533^{46}$ In 186o, Parisian workers contributed to the strike of the London builders; in 1861, the same went for bronze workers and others. The 1862 meeting between French workers visiting the Exhibition in London and British trade-unionists took place against this background, when activists felt the need for more international solidarity. This could also be seen in the address To the workmen of France from the working men of England published in the Beehive of 5th December 1863. However, as Marcel van der Linden has pointed out, this was a typically British

45 Henry Collins and Chimen Abramsky, Karl Marx and the British Labour Movement. Years of the First International (London, 1965), p. 12. On the relationship between Marx and London radicalism, also see: Keith Robinson, "Karl Marx, the IWMA, and London Radicalism, 1864-1872" (Ph.D. dissertation, University of Manchester, 1976).

46 Iorwerth Prothero, Radical artisans in England and France, 1830-1870 (Cambridge, 1997), p. 116. 
text. ${ }^{47}$ In France, the workers' population included more independent artisans and far fewer industrial wage-earners than in Britain - and Tolain's response insisted on the subversion of the artisan by big business rather than solidarity in strike action.

To come back to the initial point of origins and precursors, this paper has argued that we should not neglect the part played by militant groups and by individuals, i.e. assume that the IWMA was bound to be created because of the development of trade unions in Britain, because of the mid-Victorian boom of the 1850 and 1860 s, because the grip of repression under Napoleon III was getting less tight or because of the international exhibitions. The distinction between "external" and "internal" causes should be made with caution. As we have seen, exiles interacted with British radicals. British radicals interacted with unionists and workers all over the country. On occasions, exiles could even be involved in workers' struggles, as was for example the case of Friedrich Lessner, who played a leading part in a tailors' strike in $1866 .{ }^{48}$ Social, cultural and political factors combined in the process. Both refugees and militant workers were able to break new ground: they transformed the experience of workingmen's struggles into a new type of organization, and they related abstract internationalist beliefs to real movements into an influential structure. The legacy of the FD and the IA played a critical part. In fact, the legacy of the IA did not reside so much in its influence among the working class. In many respects, it was probably less influential than the FD had been. What these various groupings (FD, IC, IA) bequeathed to the IWMA can be summarized in a few words.

Many of those who played an important part in its construction were younger or had a different story: George Potter (b. 1832), William Randal Cremer (b. 1828), Henri Tolain (b. 1828), Eugène Varlin (b. 1839), Benoit Malon (b. 1841), César de Paepe (b. 1841) and James Guillaume (b. 1844) are just some examples. At the same time, some early internationalists had died, such as Joseph Moll. Others had emigrated like Julian Harney or Heinrich Bauer; and some exiles also refused to join, e.g. Mazzini, Louis Blanc or Babouvist worker Joseph Benoit, as they still believed social classes should unite and therefore opposed the class content of the grouping which was clear from the beginning. But the link between the period of the 1840 on and the 185 os and the IWMA was made by

47 Marcel Van der Linden, "The rise and fall of the First International: an Interpretation", p. 331 .

48 Lessner, Sixty Years in the social democratic movement. Before 1848 and After. Recollections of an Old Communist (London, 1907), p. 35. 
other exiles and early internationalists, e.g. Alfred Talandier (1822-1890), Victor Le Lubez (1824-1896), who asked Marx whether he could find a "German workman" for the 28 September 1864 meeting, which took place in the same hall where the International Association had been founded nine years earlier; ${ }^{49}$ Johann Georg Eccarius (1818-99), who was the "German workman" Marx found, and who had lived in London since 1851, and of course Marx himself; tailor Friedrich Lessner (1825-1910), who had been a member of the CABV and the League of the Just since he first came to London in 1847 and was a member of the General Council of the IWMA; ${ }^{50}$ Friedrich Sorge, who had been a German member of the IA in the Us; former Chartists like Alfred Walton (1816-83), George Odger (1813-77) or George Howell (1833-1910); former Owenites like John Weston; former FD like Karl Schapper and Ludwik Oborski; former leading members of the IC G.E. Harris and J.B. Leno, etc.

The continuities, in men, ideas, places and practices were thus essential in the making of the IWMA. However, the IWMA was different from both the FD and the IA, and neither of these groups stood at its direct origin. These international organizations were the examples of a certain globalization of working-class radicalism, a political globalization "from below", which was made despite, or even against governments as well as the social and cultural elite. Until the $185 \mathrm{os}$, these organizations still relied on the practicalities of the cultural globalization which was at work among liberal elites and literary milieus: contacts in exile, correspondence networks; newspapers; the translation of articles or books. When it was founded, the IWMA still relied on these practicalities. But unlike the FD or the IA, it did not limit its activities to propaganda or education. It was framed in a different period of time, when migration flows and the hiring of foreign labour posed new problems, when workers' trade unions, struggles strikes in particular, multiplied in Britain, France, Belgium or Switzerland. This working-class upturn was central in convincing Marx, who had refused to be involved in the gatherings

49 Letter of Marx to Engels (4 November 1864).

5o Frederick Lessner, Sixty Years.

51 Detlev Mares, "A Radical in Wales. Alfred A. Walton and Mid-Victorian Welsh Popular Radicalism", Welsh History Review, 21 (2002), pp. 271-291. 
of the 1850 , to throw himself headlong into the new association. ${ }^{52}$ Indeed, with the membership of unions and branches across Europe, the IWMA was soon not just cosmopolitan but truly international, something its predecessors had never managed.

52 "I knew that on both the London and the Paris sides real 'powers' were involved this time, and so I decided to waive my customary standing rule to decline any such invitations", Karl Marx to Friedrich Engels (4 November 1864). 


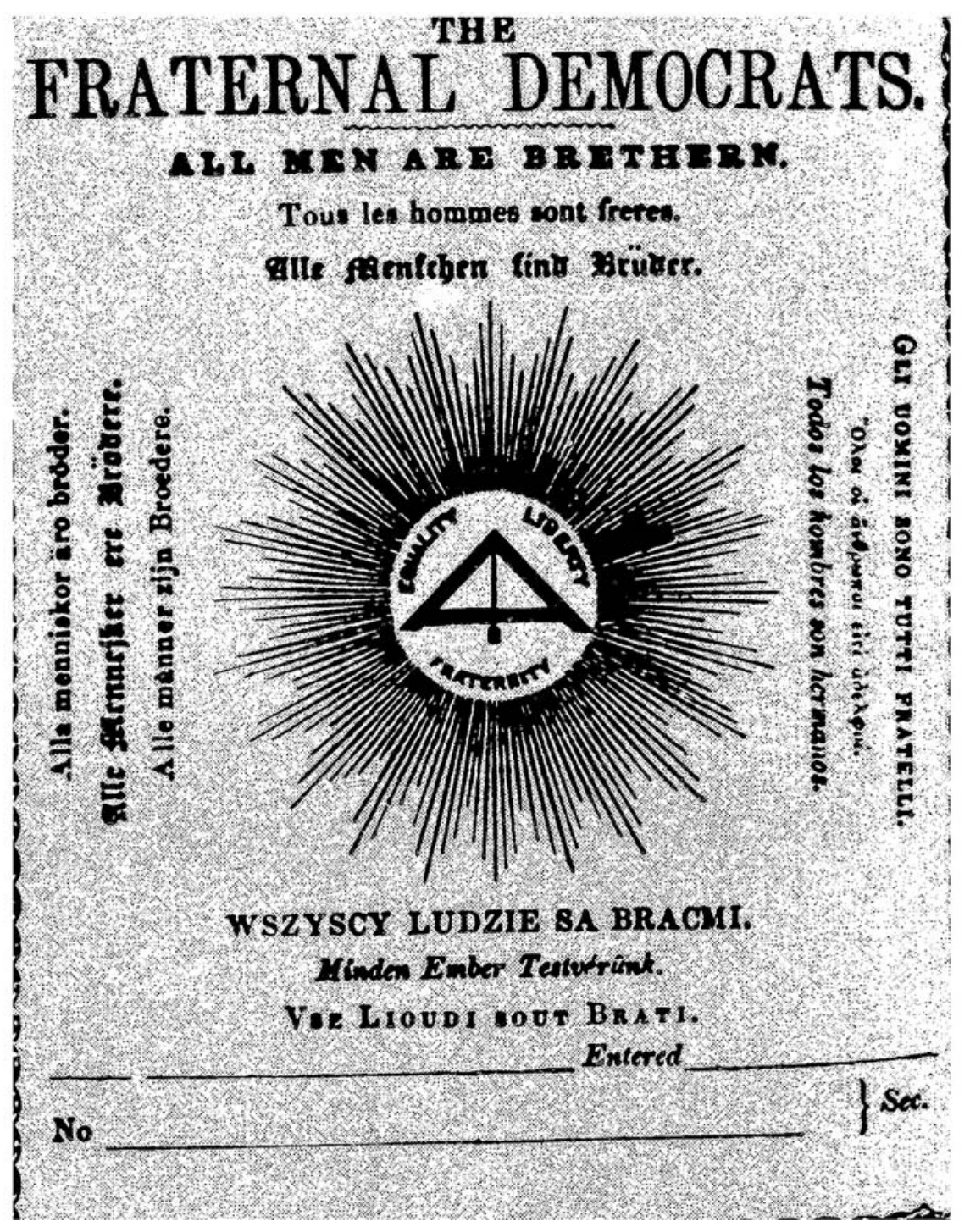

FIGURE 2.1 Membership card of the Fraternal Democrats. PRIVATE COLLECTION. 


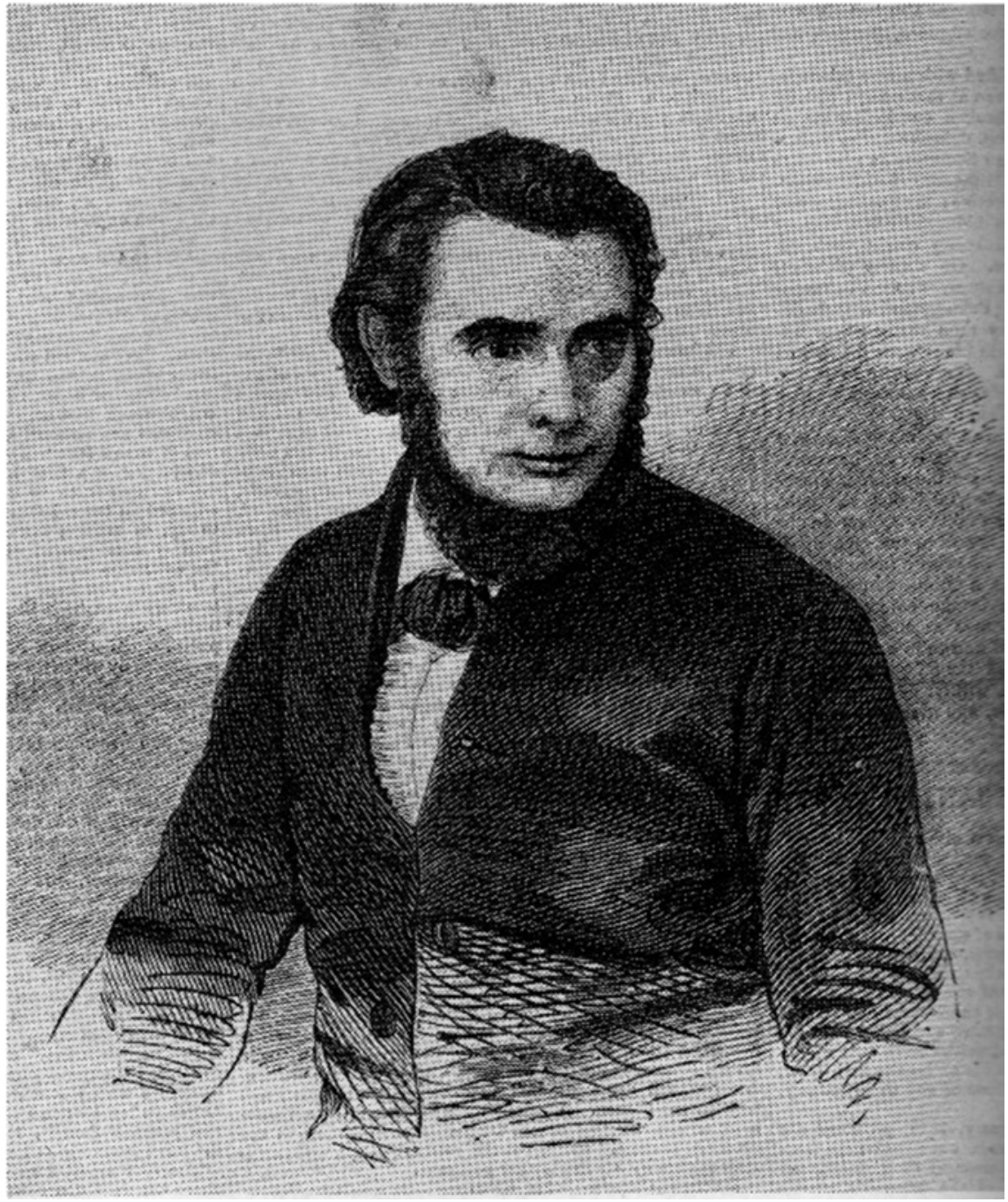

FIGU RE 2.2 George Julian Harney (1817-1897) was the founder of the Fraternal Democrats. PRIVATE COLLECTION. 